\title{
When the earth stood still: air pollution during the Covid-19 quarantine - the case of São Paulo and Rio de Janeiro
}

\author{
Quando a Terra parou: poluição do ar durante a quarentena \\ de Covid-19-O caso de São Paulo e Rio de Janeiro
}

Janaína Accordi Junkes ${ }^{a}$

Tainá Teixeira Cavalcante de Lima ${ }^{b}$

Giulia Francesca Carvalho Oliveira França ${ }^{c}$

Diego Freitas Rodrigues ${ }^{d}$

${ }^{a}$ PhD in Materials Science and Engineering, Researcher, Programa de Pós-Graduação em Sociedade, Tecnologias e Políticas Públicas, Tiradentes University Centre, Maceió, AL, Brazil E-mail: janaina.accordi@souunit.com.br

${ }^{b}$ Environmental Engineer, PhD Student, Programa de Pós-Graduação em Sociedade, Tecnologias e Políticas Públicas, Centro Universitário Tiradentes, Maceió, AL, Brazil E-mail: taina_limaa@hotmail.com

'Master in Business Administration, Master's Student, Programa de Pós-Graduação em Sociedade, Tecnologias e Políticas Públicas, Centro Universitário Tiradentes, Maceió, AL, Brazil E-mail: contato@giuliafranca.com

${ }^{d}$ PhD in Political Science, Researcher, Programa de Pós-Graduação em Saúde e Ambiente, Tiradentes University, Maceió, AL, Brazil E-mail: diegofreitasrodrigues@outlook.com

doi:10.18472/SustDeb.v12n1.2021.36259

\section{ABSTRACT}

In March 2020, the World Health Organization declared a global pandemic due to the new coronavirus (Covid-19). Several countries responded to this threat by introducing quarantine measures to reduce the transmission of Covid-19 in the community. These measures have drastically reduced human activities, causing an impact on urban air pollution due to the associated reduction in automobile use and other polluting activities. We investigated this effect with measurements of Particulate Material $\left(\mathrm{PM}_{10}\right)$, Carbon Monoxide (CO), Nitrogen Dioxide $\left(\mathrm{NO}_{2}\right)$ and Ozone $\left(\mathrm{O}_{3}\right)$, carried out by the environmental departments of the cities of São Paulo and Rio de Janeiro, for two months in 2020. We compared them with data for the corresponding months in 2019, relating to the social isolation index, measured by the Mathematics and Statistic Institute of São Paulo (IME-USP). The results show a significant decrease in $\mathrm{NO}_{2}$ and $\mathrm{CO}$ and an increase in $\mathrm{O}_{3}$, and little change in Particulate Material. 
Keywords: Air quality. Covid-19. Pollutant monitoring. Quarantine. Rio de Janeiro. São Paulo.

\section{RESUMO}

Em março de 2020, a Organização Mundial da Saúde declarou pandemia global devido ao novo coronavírus (Covid-19). Vários países responderam a essa ameaça introduzindo medidas de quarentena, visando reduzir a transmissão da Covid-19 na comunidade. Essas medidas reduziram drasticamente as atividades antrópicas, gerando impacto na poluição do ar urbano devido à redução associada no uso de automóveis e outras atividades poluentes. Investigamos esse efeito com medições de Material Particulado (MP10), Monóxido de Carbono (CO), Dióxido de Nitrogênio (NO2) e Ozônio (O3), realizadas pelas Secretarias de Meio Ambiente das cidades de São Paulo e Rio de Janeiro, durante dois meses de 2020 e os comparamos com dados dos meses correspondentes em 2019, relacionando com o índice de isolamento social, medido pelo IME-USP. Os resultados mostram diminuição significativa em NO2 e CO, e um aumento em 03, e pouca alteração no Material Particulado.

Palavras-chave: Qualidade do ar. Covid-19. Monitoramento de poluentes. Quarentena. Rio de Janeiro. São Paulo.

\section{INTRODUCTION}

The Chinese Center for Disease Control and Prevention reported unexplained pneumonia cases in Wuhan on December 31, 2019. An epidemiological investigation indicated the origin of this new disease was a wet market in the south of the city. On January 1,2020, the market was closed, and on January 3, the Chinese government notified the World Health Organization (WHO) of the new disease. On January 7, the disease caused by this coronavirus (SARS-CoV-2) was named Covid. It soon became apparent that SARS-CoV-2 was more contagious than SARS-CoV and MERS-CoV and had a relatively higher mortality rate. On January 23, Wuhan was isolated, and two days later, an emergency state was declared in China (YANPING, 2020).

The disease spread quickly, affecting people belonging to certain groups more severely: adults over 60 and people with pre-existing conditions, such as diabetes and heart diseases (PAN AMERICAN HEALTH ORGANIZATION, 2020). Due to the large numbers of infected people who needed hospitalization, governments began to worry about the collapse of their respective health systems - a rather serious problem in developing countries where health systems are often poorly funded. As the disease spread globally, many countries followed China's imposed quarantine strategy (restrictions on public movement), allowing only essential services to function. The government adopted several measures to prevent people from having contact with each other (social isolation), to reduce community transmission of Covid-19.

Notwithstanding the dire economic consequences of such enforced social isolation, the massive reduction in human activities in major urban centres also had some positive aspects. For example, the absence of human disturbance allowed wild animals to encroach onto urban areas, such as ducks and fish seen in Venice canals (SHARMA, 2020). Also, a significant decrease in noise levels, in the city of Rio de Janeiro, was noticed, especially downtown (DIAS et al., 2020). Perhaps most significantly, pollution levels began to fall and visibility increased with the Himalayas being visible from India for the first time in decades (ROY, 2021). In a study carried out in England, Travaglio et al. (2020) concluded that a small increase in air pollution leads to higher Covid-19 infection and mortality rate. Freitas et al. (2020) found out that mobility reduction in São Paulo had a direct impact on air pollution and an indirect one on the spread, among the population, of some infectious diseases.

Thus, imposed quarantines provided a unique opportunity to study the effects of dramatically reduced human activities on air pollution (MUHAMMAD et al., 2020). Several countries have adopted different 
policies for containing the pandemic with greater or lesser success rates (HSIANG et al., 2020; KIM; CASTRO, 2020; MAIER; BROCKMANN, 2020). Therefore, the decrease in air pollution can be an indicator of the reduction of anthropogenic activities.

Air pollution can be characterized, as the presence of matter and/or energy harmful to health, materials and the environment, with a natural or anthropogenic origin. These pollutants can be classified as primary, emitted directly from a source, or secondary, formed from chemical reactions between primary pollutants and other substances (SANTOS, 2017). Since the industrial revolution, air pollution generated by human actions has dramatically increased, despite national legislation and several international agreements and treaties aiming to reduce gas emissions.

Some models indicate a non-linear relationship between economic growth and pollution through regressions generating inverted " $U$ " curves (Figure 1). This is explained by pollution initially accompanying the growth of national production (the "income effect") but when a certain level of income is reached, environmental quality begins to grow in parallel with GDP per capita. The common point of the econometric models that use the Kuznets Environmental Curve is the estimation of a quadratic relationship between (1) the measure of environmental degradation, such as $\mathrm{CO}_{2}$ emissions per capita, and (2) per capita income for the test realization of the inverted " $U$ " design observed in this curve (AGRAS; CHAPMAN, 1999). In this model, if the initial capital stock in an economy is low, emission rates will increase even though there is a declining trend with time. Conversely, if the initial capital stock in the economy is high, there will be a drop in pollutant emission rates due to economic growth, creating an encouraging "state of equilibrium".
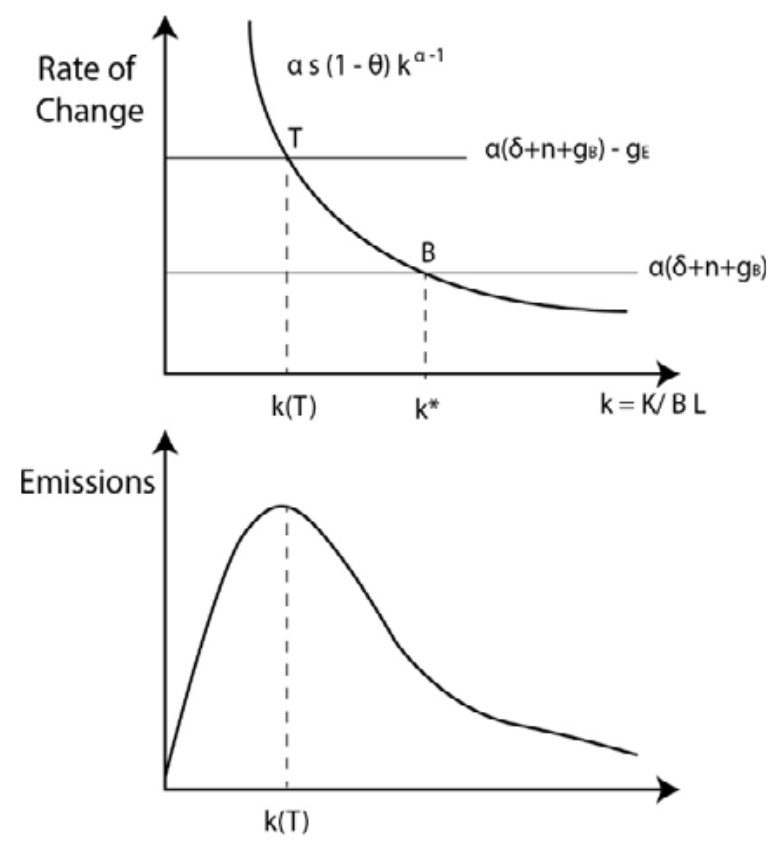

Figure 1 | Ambiental curve of Kuznets. Source: Agras e Chapman, 1999.

Covid-19 officially arrived in Brazil at the end of February 2020. Less than a month after this first case was reported, the WHO declared a global pandemic. Locations with the highest number of cases in the country, such as São Paulo and Rio de Janeiro, began to decree quarantines (DEBONE et al., 2020; FAíCO-FILHO et al., 2020). In the present article, we investigate the effect of quarantines on air pollutants in São Paulo and Rio de Janeiro. We performed this analysis on daily data provided by the respective city environmental departments for Ozone $\left(\mathrm{O}_{3}\right)$, Nitrogen Dioxide $\left(\mathrm{NO}_{2}\right)$, Particulate Material $\left(\mathrm{PM}_{10}\right)$ and Carbon Monoxide (CO). 


\section{REFLECTIONS ON THE INTERNATIONAL QUARANTINE}

Quarantines are measures to increase social isolation, reducing people traffic on the streets and physical interactions between people in general. Except for services considered essential (food and medicine stores), most quarantine orders recommended the general population to remain at home (known colloquially as 'lockdown'). These measures caused an enormous decrease in urban activities, from vehicle circulation to the temporary closure of companies, and it also resulted in an environmental quality change worldwide.

Satellite images (Figure 2) from National Aeronautics and Space Administration (Nasa) show the reduction of atmospheric pollution in locations that enforced a quarantine. The press has also published visualizations that show the reduction of nitrogen dioxide emissions $\left(\mathrm{NO}_{2}\right)$ in China, mainly in the Wuhan region (LIAN et al., 2020) and in Italy (COKER et al., 2020). Comparing satellite images from March 2019 with those from March 2020, it is also possible to observe reduced pollution areas in France, Italy, and Germany, indicating a fall in $\mathrm{NO}_{2}$ levels.

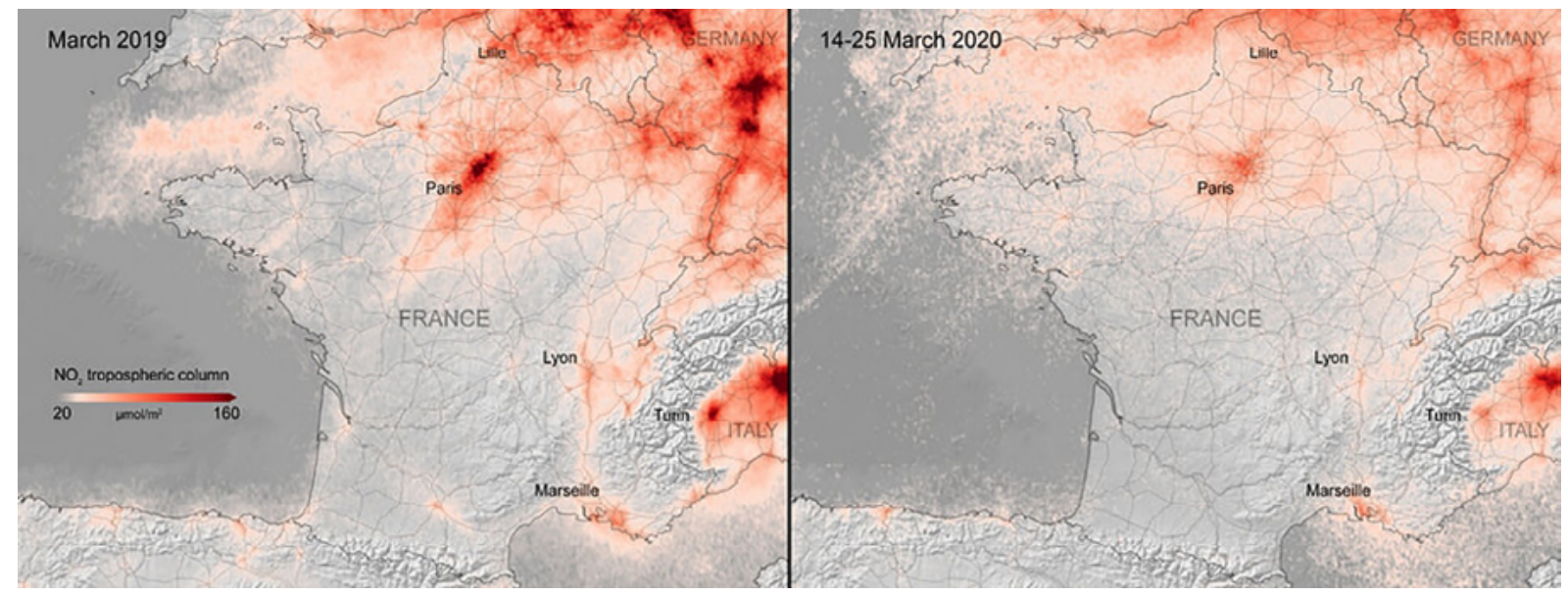

Figure 2 | NO decrease in Europe in March 2020. Source: National Aeronautics and Space Administration, 2020.

In addition to the negative impact of Covid-19 on public health, there was also a significant reduction in air pollution in several Chinese cities. Nitrogen dioxide $\left(\mathrm{NO}_{2}\right)$ emissions attributable to economic activities reduced in China after the first announced cases of Covid-19 in the country. This is significant, given that China contains many cities with high levels of air pollutants and corresponding impacts on public health. China's development heavily relies on the coal industry and automobile production, resulting in serious air degradation. Despite the impacts of isolated pollutants, the mix of pollutants generated by these industries (which varies according to the time of year) can have serious health consequences. For example, Han et al. (2018) obtained data from 155 Chinese cities for $\mathrm{PM}_{2,5}, \mathrm{PM}_{10^{\prime}}, \mathrm{NO}_{2}, \mathrm{SO}_{2}$ (sulfur dioxide) and $\mathrm{O}_{3}$. They estimated $36 \%$ of the studied population (about 142 million inhabitants) suffer from exposure to concentrations higher than recommended by the $\mathrm{WHO}$ for $\mathrm{PM}_{2,5} \mathrm{PM}_{10}$ and $\mathrm{NO}_{2}$. Besides, all cities were exposed annually to high concentrations of mixtures of these pollutants.

One of the effects of air pollution is a high demand for primary health care due to chronic respiratory diseases, particularly affecting children and the elderly. Gavinier and Nascimento (2014) state that even when air pollutants levels are reduced by public policies to mitigate health damage, there are still significant impacts on people's health, especially children, people with cardiovascular and respiratory diseases and the elderly. According to the publication "El impacto global de la Enfermedad Respiratoria" (2017) produced by the Asociación Latinoamericana de Tórax and Foro de las Sociedades Respiratorias Internacionales, air pollution causes more than 7 million deaths per year. Significantly, a high concentration of pollutants in urban areas also directly impacts Covid-19 mortality. High levels of pollution in cities can cause chronic respiratory diseases. In turn, this reduces the survival chances of those with SARS-CoV- 2 . 
Therefore, quarantine measures reduce community transmission of Covid-19 and improve air quality and associated respiratory disease symptoms. Moreover, the improvement in air quality can be significant. Nasa satellite images (Figure 3) showed enormous changes in $\mathrm{NO}_{2}$ values in three different periods in 2020: from January 1 to 20 (before the Chinese New Year), from January 28 to February 9 (around the Chinese New Year celebrations) and from February 10 to 25 (after the Chinese New Year celebrations).
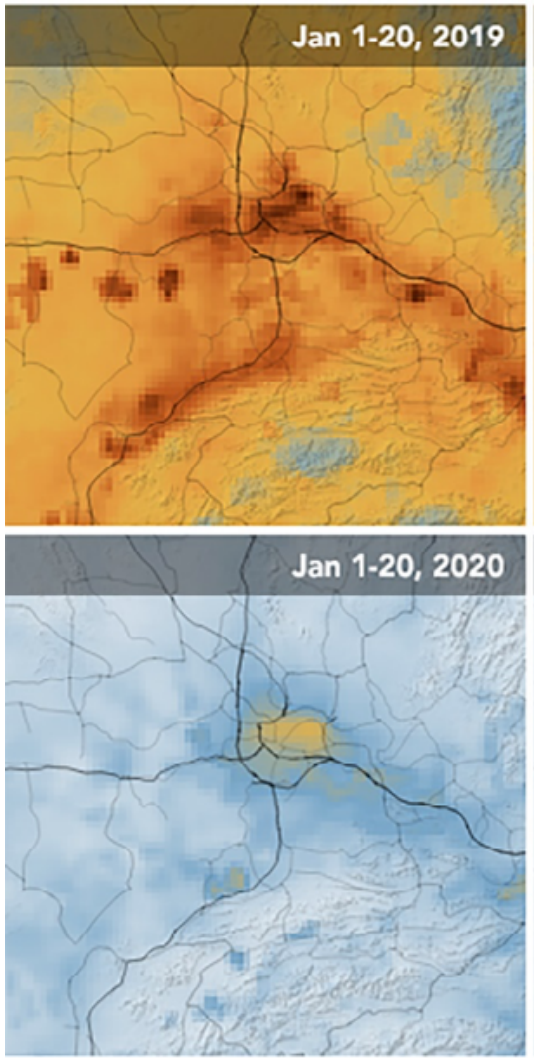
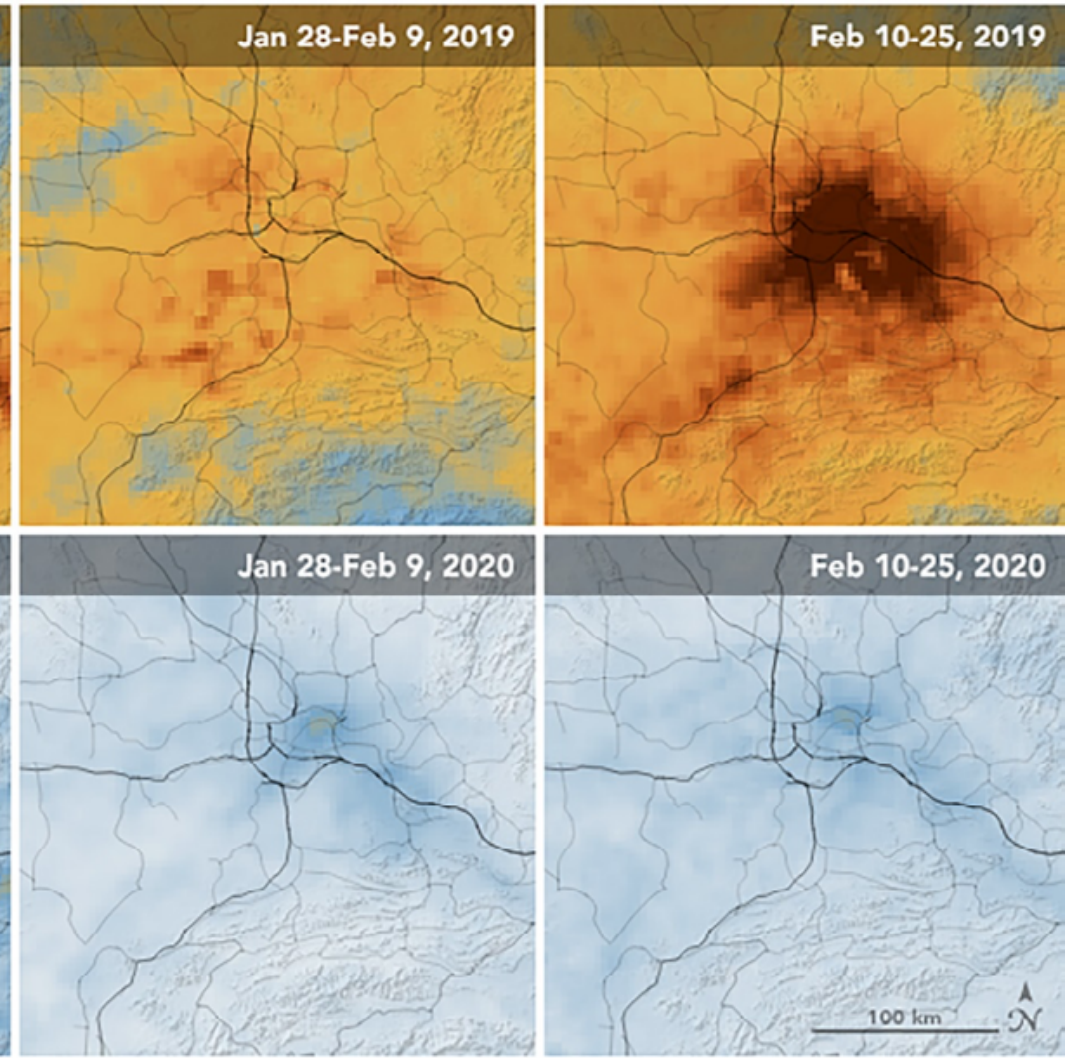

Mean Tropospheric $\mathrm{NO}_{2}$ Density $\left(\mu \mathrm{mol} / \mathrm{m}^{2}\right)$

ó $\quad 125 \quad 250 \quad 375 \quad \geq 500$

Figure 3 | Air pollution comparison in Wuhan between 2019 and 2020 from January 1 to February 25.

Source: Nasa, 2020.

From analyzing the images, we can verify a drop in air pollution during the quarantine in Wuhan.

Lian et al. (2020) observed that after the lockdown in Wuhan, the monthly average in the air quality index (AQI) was 59.7. This is 33.9\% lower than before the lockdown imposed by Chinese authorities in January of 2020. When compared with data from 2015 to 2019, it was $47.5 \%$ lower than the average. The AQI reports daily air quality and indicates how clean or harmful the air is, and it is associated with the effects that air pollution can have on public health. This index is calculated using ozone at ground level, particulate matter, carbon monoxide and sulfur dioxide, ranging from 0 to 500 , classified as good, moderate, harmful to sensitive groups, harmful, very harmful, and dangerous (EPA, 2009).

$\mathrm{NO}_{2}$ is produced by biomass burning, and its emission generally occurs with nitric oxide (NO). Since this gas can be generated both by anthropogenic activities and by the interaction with other gases in the atmosphere, it can be both a primary and a secondary pollutant (MANAHAN, 2013, p. 282; MARTINS; DE ANDRADE, 2002). In the urban environment, $\mathrm{NO}_{2}$ emissions are strongly associated with fossil fuels burning, usually with peaks twice a day corresponding to the rush hour. When characterized as a secondary pollutant, its production is associated with the interaction between NO and $O_{3}$ (KURIYAMA; MOREIRA; SILVA, 1997). 
Carbon monoxide (CO) produced by anthropogenic sources is mostly attributable to industrial processes and vehicle engines that use gasoline or diesel fuel. These two sources cause about $80 \%$ of carbon monoxide emissions in the atmosphere (PERES, 2005; TÉLLEZ; RODRÍGUEZ; FAJARDO, 2006). Vehicle emissions cause a high concentration of this pollutant in places with high traffic levels, especially in enclosed areas such as tunnels and (enclosed) parking lots.

Particulate matter is commonly present in the atmosphere, but it can cause health problems when found in particles with a diameter of less than $10 \mu \mathrm{m}$ since these can pass through the natural protection mechanisms of the respiratory system and become lodged in the lungs. Its formation is often linked to anthropogenic actions, especially the burning of fossil fuels (MANAHAN, 2013, p. 871). Cars, incinerators, and thermoelectric plants are major generators of this pollutant (CANÇADO et al., 2006).

Ozone $\left(\mathrm{O}_{3}\right)$ occurs naturally in the atmosphere, but it is a pollutant at ground level. Its formation is linked to the presence of nitrogen oxides $\left(\mathrm{NO}_{x}\right)$ and hydrocarbons from vehicle emissions, industries, and thermoelectric plants, making it a secondary pollutant that potentially harms biological organisms due to its high corrosivity (MARTINS; DE ANDRADE, 2002).

\subsection{QUARANTINE IN BRAZIL: SÃO PAULO AND RIO DE JANEIRO}

Brazil had its first case of Covid-19 confirmed on February 25, 2020 (DEBONE et al., 2020), and its first death confirmed on March 17. The Municipality of São Paulo declared an emergency through Municipal Decree 59.283 and closed non-essential trade on March 20 (SÃO PAULO, 2020a), accelerating the social isolation process. On the same day (March 20), the state government decreed a statewide public calamity with State Decree 64.879 (SÃO PAULO, 2020b), and quarantine for the entire state was decreed two days later (March 22) by State Decree 64.881 (SÃO PAULO, 2020c). A few days later, on April 17, State Decree 64.946 (SÃO PAULO, 2020d) extended all measures until May 10.

Rio de Janeiro followed closely behind São Paulo, with the first confirmed case on March 5 (BRASIL, 2020). Measures to combat the spread of the new disease took place in parallel to those in the State of São Paulo. On March 17, the Government of the State of Rio de Janeiro decreed (State Decree 46.973) the closing of gyms, cinemas, and theatres, a suspension of school/university classes and public events, and a reduction in shopping mall opening hours, number of bars and municipal bus fleet (RIO DE JANEIRO, 2020a). The opening of only essential services was decreed on March 20 with Municipal Decree 47.282, starting on March 30 (RIO DE JANEIRO, 2020c). Shortly after, on March 27, the list of essential services was expanded in the city of Rio de Janeiro with decree 47.301 (RIO DE JANEIRO, 2020d). The measures were relaxed again on April 7 by State Decree 47.025 (RIO DE JANEIRO, 2020e), opening commercial activity in cities without Covid-19 notification.

\section{METHODOLOGY}

We selected São Paulo and Rio de Janeiro for this comparison because they publish daily reports with data on air quality. Data was collected from automatic monitoring stations. For this study, we collected data from nine stations in Rio de Janeiro and seventeen stations in the city of São Paulo, using those that had available and updated data in real-time for the study period in each location.

Air quality monitoring in São Paulo is performed by the Environmental Company of São Paulo State (Cetesb), and data disclosure is through the Qualar system. In Rio de Janeiro, the monitoring depends on the Municipal Environment Secretariat (Smac) through the program MonitorAR - a result of the agreement between the city hall and Petrobras. Data disclosure is through daily reports that are available online. 
The selected pollutants to this article are carbon monoxide $(\mathrm{CO}), 10 \mu \mathrm{m}$ particulate material $\left(\mathrm{PM}_{10}\right)$, ozone $\left(\mathrm{O}_{3}\right)$ and nitrogen dioxide $\left(\mathrm{NO}_{2}\right)$. The selected cities monitor other pollutants, but the above pollutants are common to both monitoring programs. General air quality norms for Brazil are determined by the National Environment Council (Conama). According to the Resolution Conama 03/1990, CO should not exceed the average concentration in eight hours of 10,000 micrograms per cubic meter of air (9 ppm) more than once a year; particulate material should not exceed a 24-hour average concentration of 150 micrograms per cubic meter of air more than once a year; and finally, $\mathrm{NO}_{2}$ should not exceed an hourly average concentration of 320 micrograms per cubic meter more than once a year (MINISTÉRIO DO MEIO AMBIENTE, 1990).

The pollutant data collected for the present study reports daily averages for each pollutant based on up to 24 measurements (one per hour) by each weather station. After data tabulation, daily averages were calculated for the two cities. We note that not all stations had measurements for all days in the selected months (February, March and April 2019 and 2020) due to lack of calibration. Such gaps do not necessarily reflect all sensors. The measures follow Conama 03/1990 resolution norms, and therefore, are comparable.

The Social Isolation Index of the cities was obtained from the Institute of Mathematics and Statistics of São Paulo (IME-USP). The institute measures the percentage of citizens following isolation recommendation.

The data comparison was first done observing pollutant behaviour for 2 years $(2019,2020)$. After March 20, the analysis of pollutant behaviour was based on the dates of decree implementation and recommendation of social isolation and closing services.

\section{RESULTS AND DISCUSSIONS}

Not everyone in São Paulo and Rio de Janeiro followed the recommendations of social isolation, often for economic reasons (JONES; PALUMBO; BROWN, 2020) or because they are sceptical regarding such measures (ANDERSEN et al., 2020). This scepticism is, in part, a result of high volumes of fake news about Covid-19, many of which seek to diminish the seriousness of the public health crisis (GALHARDI et al., 2020). Pronouncements of Brazil's current president, who believes public health should not always be above economic health, may have exacerbated non-compliance (FERNANDES et al., 2020). Beyond that, many people work in essential services who had to continue working as usual. These factors are reflected in the Social Isolation Indices for São Paulo and Rio de Janeiro cities of around 50\% (around half of the population staying at home) since March 20 (Figure 4). 


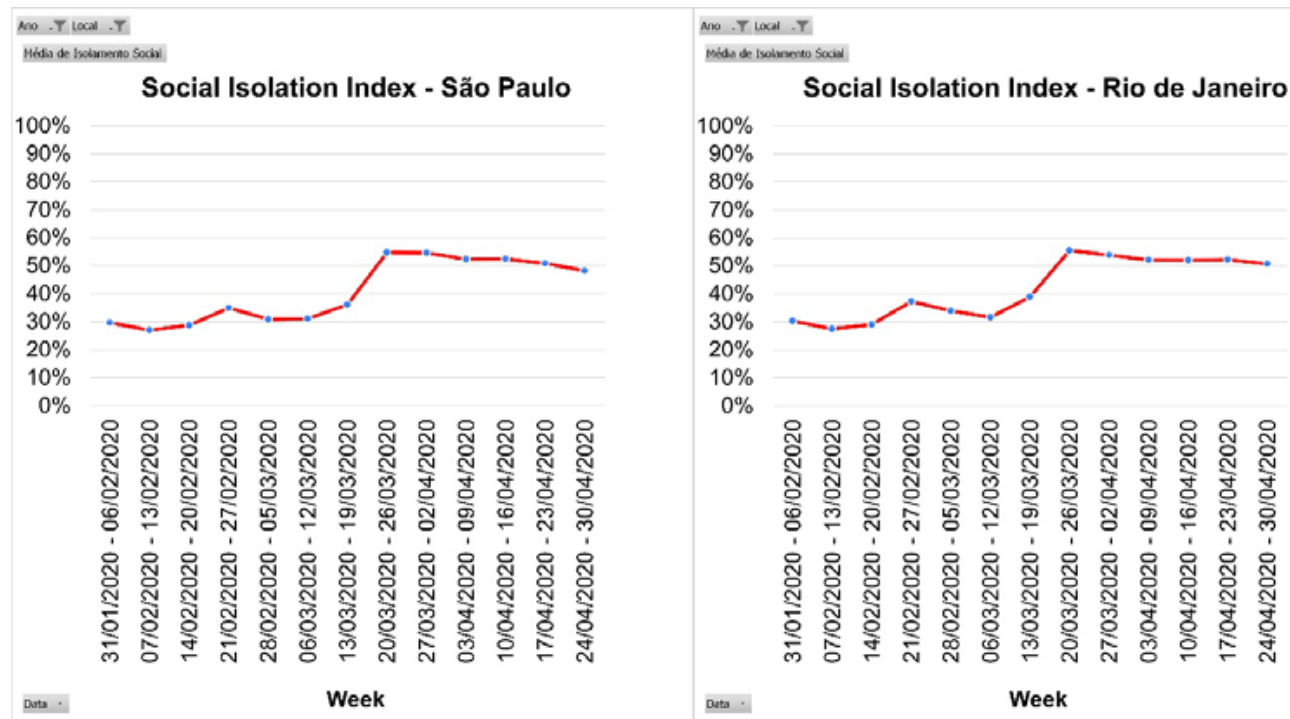

Figure 4 | Social isolation index in the states of São Paulo and Rio de Janeiro, from January 31 to April 30, 2020. Source: Elaborated the authors.

We compared our data on pollutants with equivalent data from the same period in 2019 to demonstrate the probable effect of the quarantine. We should mention that there is a considerable natural variation to climate dynamics (precipitation and temperature) that influence the formation and/or dispersion of pollutants. The pollutants in our study are all directly connected with vehicle emissions, apart from $\mathrm{O}_{3}$ that is formed by the interaction of gases released by vehicles, $\mathrm{NO}_{x}$ and hydrocarbons. Thus, pollution is linked to the number of cars circulating in the studied cities. The São Paulo vehicle fleet exceeded 29 million in the year 2018, with 18.2 million automobiles. The city of Rio de Janeiro contains 2.8 million vehicles, of which 2 million are automobiles (INSTITUTO BRASILEIRO DE GEOGRAFIA E ESTATÍSTICA, 2018a, 2018b).

The levels of $\mathrm{CO}$ (Figure 5) plummeted during quarantine compared with the previous month and data from 2019. It is important to note that quarantine officially started in São Paulo and Rio de Janeiro, respectively, on March 20 and 30 of 2020. However, the recommendation to initiate social isolation began between March 17 and 18 for both locations, causing an immediate reduction in motor vehicle use. Burning gasoline is the main cause of $\mathrm{CO}$ emissions, along with aldehydes and hydrocarbons (UEDA; TOMAZ, 2011). Automobiles and motorcycles burn gasoline and/or ethanol and are responsible for most emissions of this pollutant. According to a published report by Cetesb (2018), gasoline has higher annual consumption than ethanol in Brazil. In 2017, gasoline vehicles were responsible for more than 74,000 tons of $\mathrm{CO}$ emission in the São Paulo metropolitan region, more than half of the total produced in the year, while diesel-burning was responsible for 7,100 tons of emissions. 

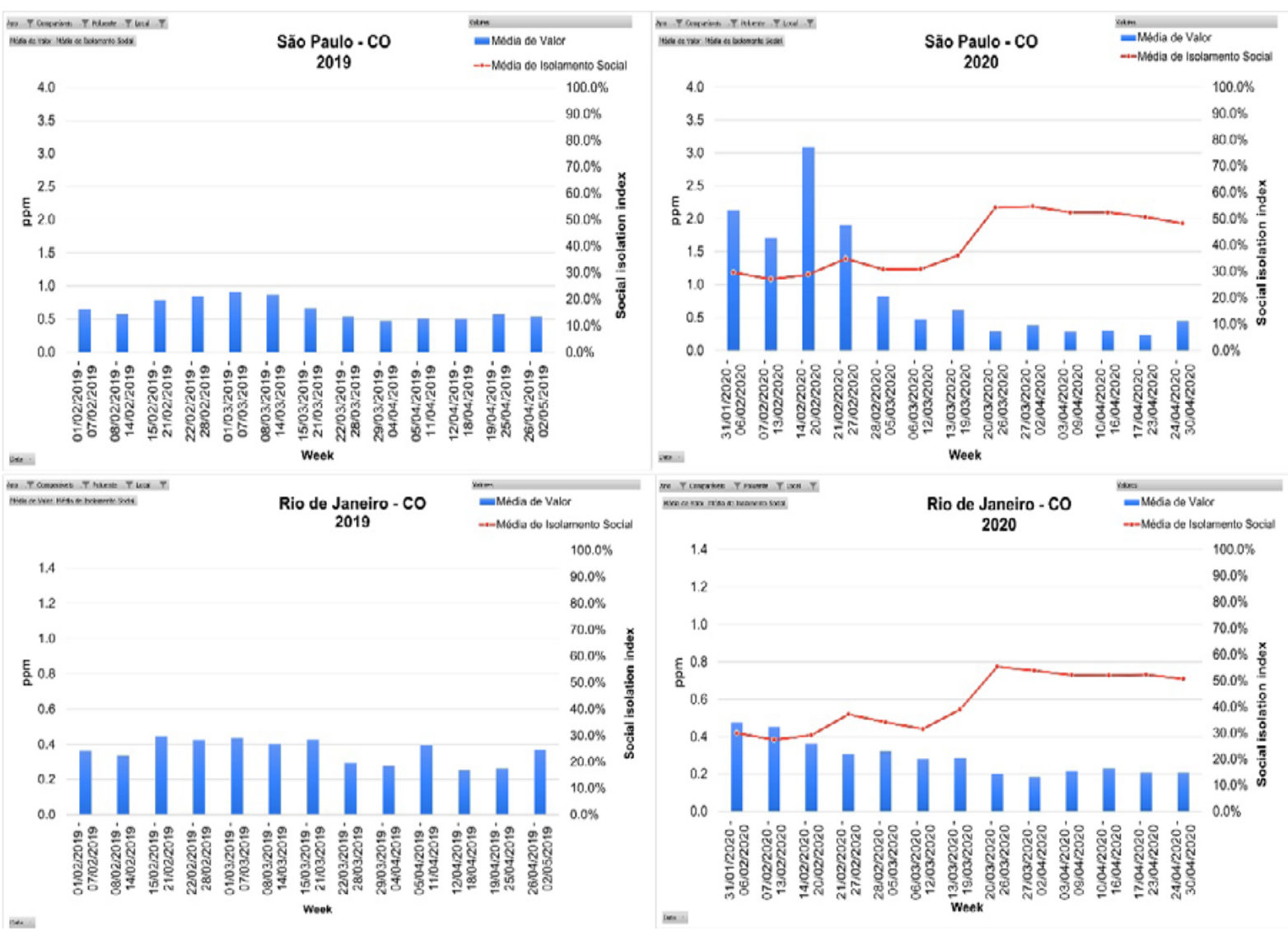

Figure 5 | CO values for the months of February, March and April. Source: Elaboration of the authors.

In 2013, automobiles emitted $80 \%$ of $\mathrm{CO}$ in the Rio de Janeiro Metropolitan Region (INSTITUTO ESTADUAL DO AMBIENTE, 2016). In our analysis, CO was lower in both cities for all days of the study period compared to the year before.

São Paulo suspended its policy of vehicular rotation (SÃO PAULO, 2020e), and companies had to adopt home-office, resulting in a car reduction on the streets. Similarly, Rio de Janeiro implemented it for public service officials and closed leisure areas, tunnels and many roads, in addition to restricting activities to essential services. This reduced the need for personal mobility and significantly diminished the number of passenger vehicles on the streets (RIO DE JANEIRO, 2020f, 2020g).

Particulate material was the only pollutant we assessed that did not show a consistent decline in response to quarantine measures in São Paulo and Rio de Janeiro (Figure 6). However, more than half of particulate material comes from trucks, particularly from heavy and semi-heavy ones. Moreover, diesel vehicles are responsible for almost all the pollutant production, and their use may have been less affected by quarantine measures (CETESB, 2018). In other words, despite the significant decrease in vehicles on the streets, many of the biggest emitters (cargo vehicles) remained active. The $\mathrm{PM}_{10}$ levels may also be connected to widespread non-compliance with state legislation. 

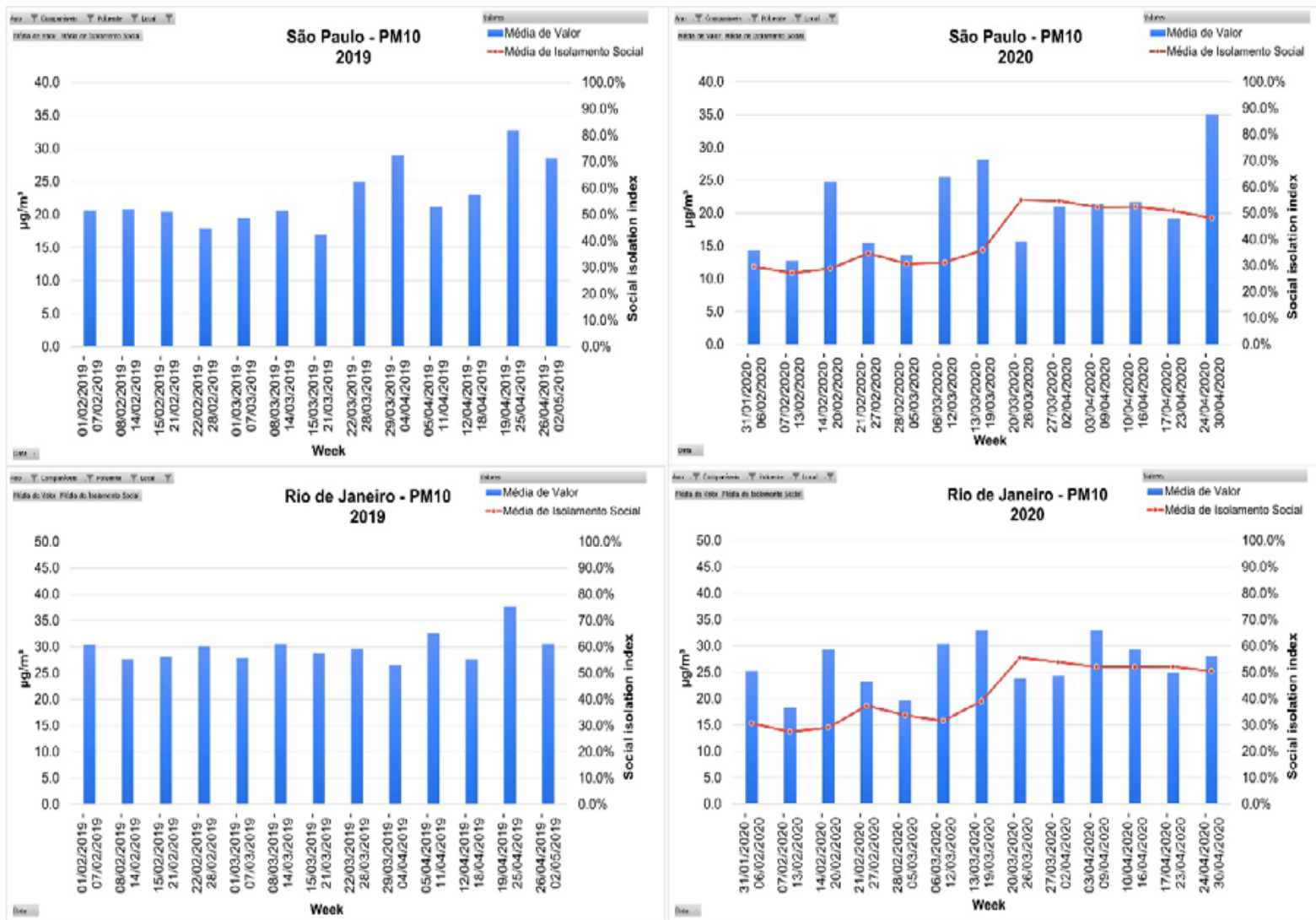

Figure 6 | $\mathrm{PM}_{10}$ values for the months of February, March and April. Source: Elaboration of the authors.

As mentioned above, diesel oil burn is the principal cause of $\mathrm{NO}_{\mathrm{x}}$ emission and, to a lesser extent, $\mathrm{CO}$ emission (KOSLOWSKI et al., 2014). Big vehicles, such as buses and trucks, typically use diesel and are therefore responsible for most $\mathrm{NO}_{x}$ emissions. According to the Cetesb report, diesel use in the São Paulo state is higher even than gasoline. In 2007, diesel burn in the São Paulo Metropolitan Region was responsible for 35,000 tons of 46,200 tons of $\mathrm{NO}_{x}$ emissions that year, compared to 7,100 tons produced by gasoline motors (COMPANHIA AMBIENTAL DO ESTADO DE SÃO PAULO, 2018).

The report on vehicle emission in Rio de Janeiro Metropolitan Region is based on the year 2013. The $\mathrm{NO}_{\mathrm{x}}$ emission for that year is $81.2 \%$ attributable to diesel vehicles (INSTITUTO ESTADUAL DO AMBIENTE, 2016). $\mathrm{NO}_{2}$ values fluctuate a lot in both cities, probably from truck traffic. São Paulo receives and sends considerable freight to the nearby Santos port, while Rio de Janeiro also receives/sends goods from its ports. Both cities also have hundreds of urban buses circulating every day.

São Paulo city kept only 55\% of buses in circulation after March 24 and recorded a $70 \%$ reduction in passengers. Additionally, heavy vehicles used for transportation of medicines, water, food, fuel, necessities and gas, were allowed to circulate at any time of the day or night during the quarantine period (SÃO PAULO, 2020e, 2020f, 2020g). Rio de Janeiro and São Paulo suspended some restrictions on loading and unloading vehicles to maintain essential supplies. Nevertheless, both cities cut some Bus Rapid Transit (BRT) and interstate passenger transportation from São Paulo, Minas Gerais, Espírito Santo, Bahia, Federal District and other states with Covid-19 confirmed outbreaks (RIO DE JANEIRO, 2020b, 2020h).

The decrease in the public transport fleet is greatly responsible for low $\mathrm{NO}_{2}$ values in both cities (Figure 7). Nevertheless, epidemic peaks may be related to the "augmented" circulation of trucks transporting essential items, especially considering high traffic of this kind of vehicles occurs during the night in "regular" times and during the pandemic, the demand for PPE increased. Both cities also had to build field hospitals due to a shortage of hospital beds, although the field hospital in Rio de Janeiro only opened in late April (G1 RIO, 2020). 

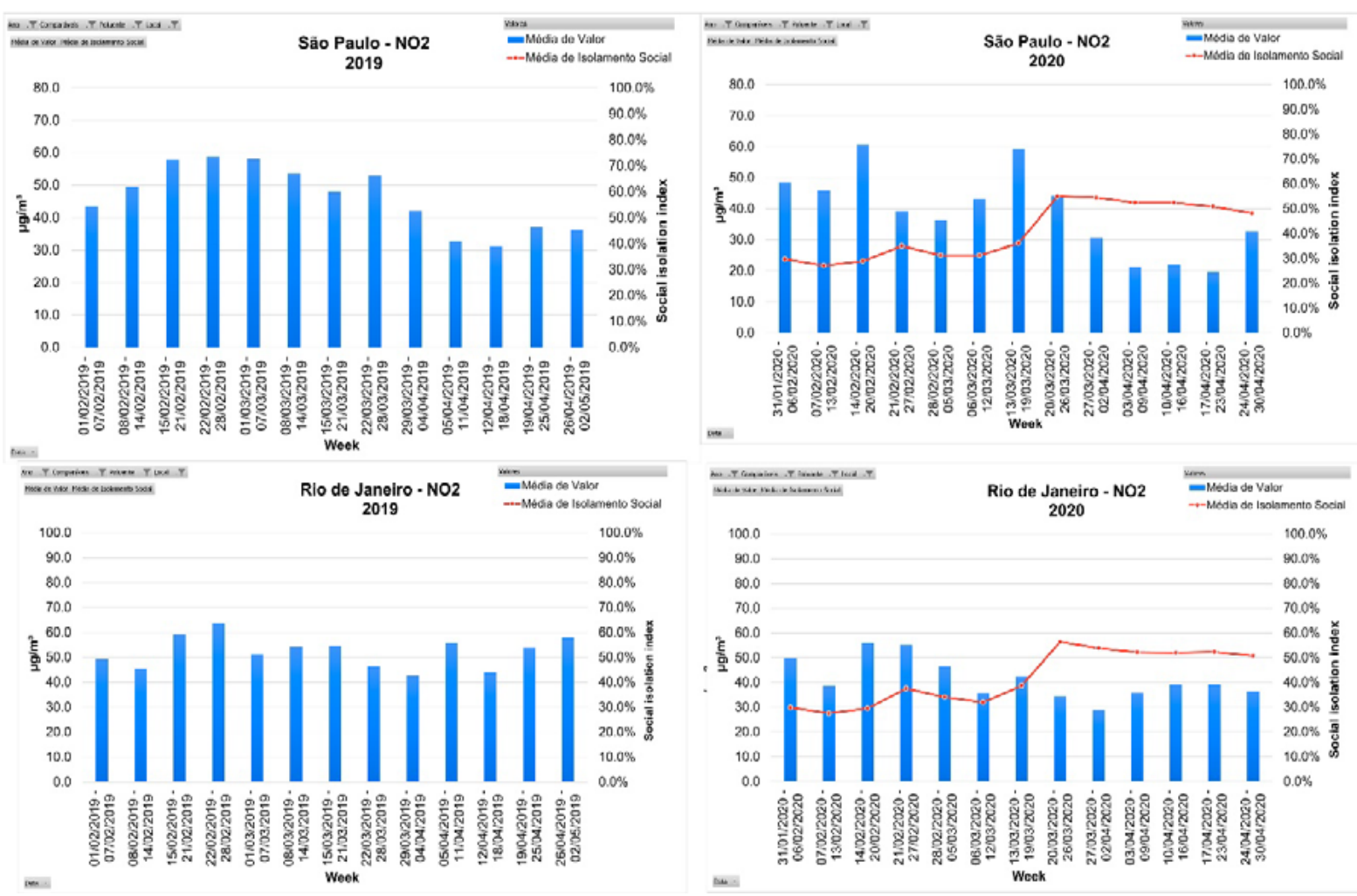

Figure 7 | $\mathrm{NO}_{2}$ values for the months of February and March. Source: Elaboration of the authors.

As reported, ozone is a harmful gas when it occurs close to ground level. It is highly reactive, interacting easily with nitrogen oxides, so the relationship between $\mathrm{NO}_{x}$ and $\mathrm{O}_{3}$ is typically inversely proportional. Once nitrogen oxides reduce, there is an accumulation of $\mathrm{O}_{3}$ linked to a decrease in its consumption (SOUZA et al., 2018).

$\mathrm{NO}_{2}$ fell in São Paulo after March 18 and, despite the drop of $\mathrm{O}_{3}$ by almost $50 \mu \mathrm{m}$ between March 18 and 19, an increasing trend followed (Figure 8). In Rio de Janeiro, $\mathrm{NO}_{2}$ levels followed a similar pattern for the three months, with a significant drop only between March 28 and 29. This explains why $\mathrm{O}_{3}$ remained low in the days after March 20. 

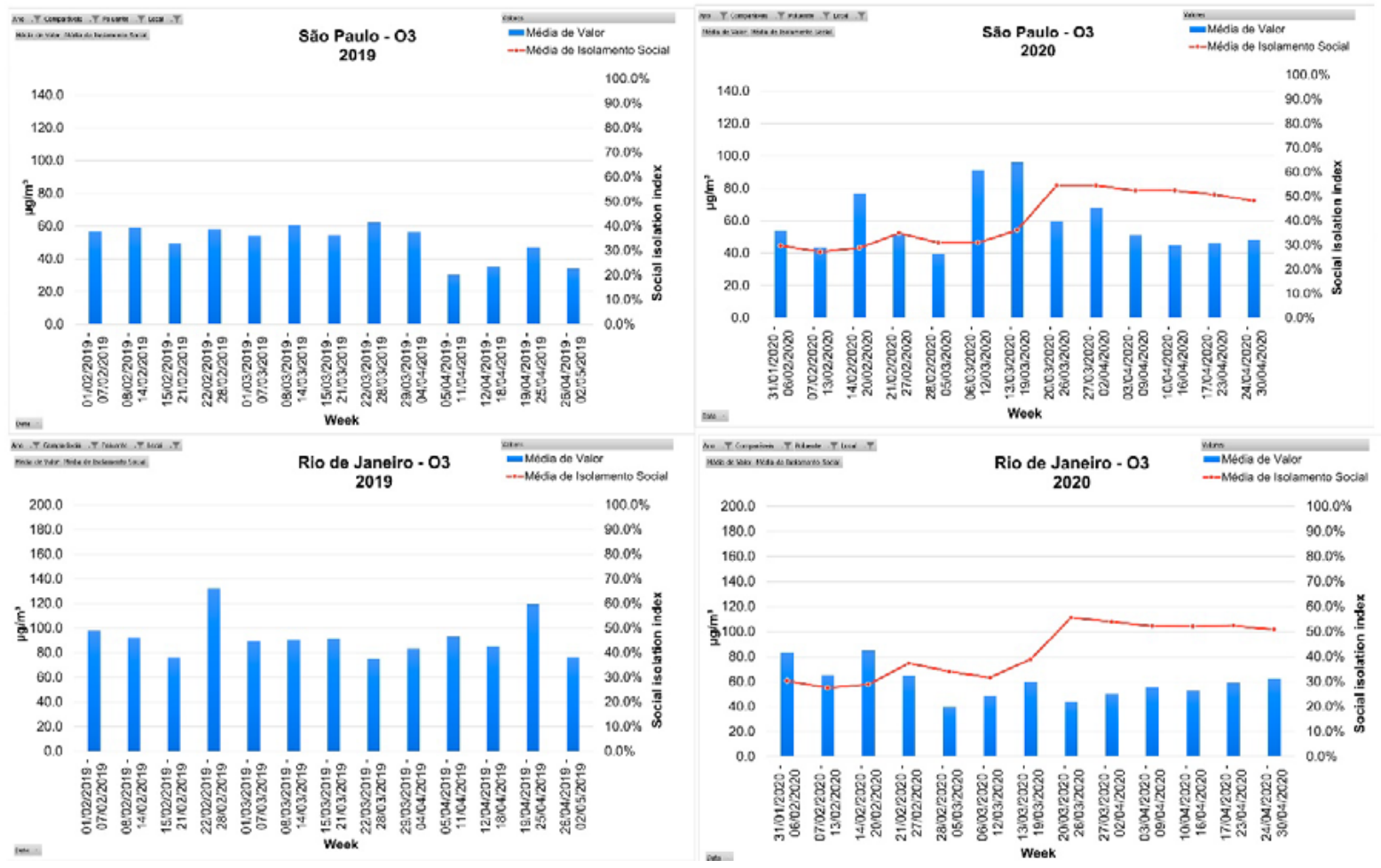

Figure $8 \mid \mathrm{O}_{3}$ values for the months of February and March. Source: Elaboration of the authors.

São Paulo city is super moist and with average temperatures between 10ㄷ and 15ㄷ (SECRETARIA DE ENERGIA, 2012). Moreover, it is a city with very high buildings that limit wind circulation and hinder pollutant dispersion. Cold air associated with humidity makes air dense, concentrating pollution near the ground. This can be a critical factor in particulate material accumulation (these particles, though very small, are heavier than gases and therefore disperse less readily). In contrast, Rio de Janeiro city is typically hot and moist, with an annual average temperature of $22^{\circ} \mathrm{C}$ and typical highs of $30^{\circ} \mathrm{C}$ to $32^{\circ} \mathrm{C}$. From December to March the city also experienced frequent and intense precipitation (RIO DE JANEIRO, 2009). Higher temperatures facilitate pollutant dispersion, even when humidity is high. This may have contributed to keeping levels of particulate material in Rio de Janeiro lower for longer than in São Paulo (Figure 9).

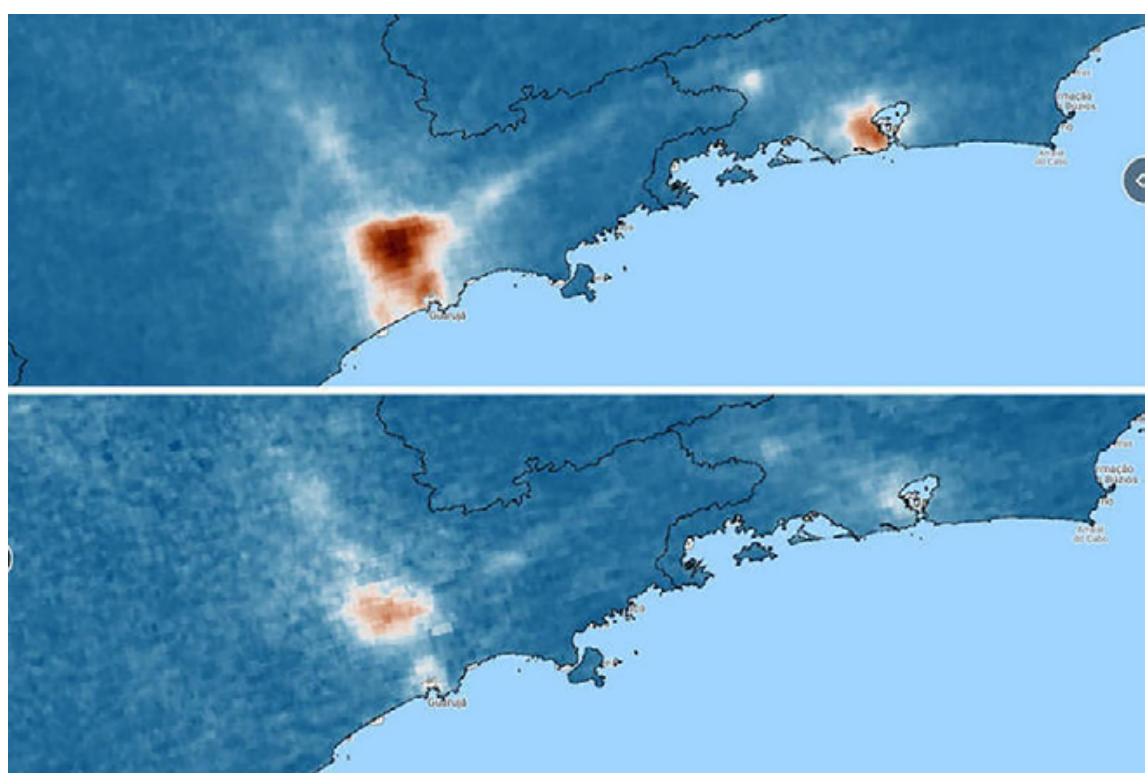

Figure 9 | Reduction of the pollution spot in Rio de Janeiro, comparing April 1, 2019, with the same date in 2020. 
Average temperatures and wind regimes can also influence the visibility of pollution. São Paulo's air density means pollution can often be seen, sometimes giving the impression the city is enclosed by a dense grey dome. In contrast, Rio de Janeiro has "invisible" air.

Similar declines in pollution have been observed in some of the World's other megacities. For example, Delhi in India (one of the 20 most polluted cities in the world) recorded falls in $\mathrm{PM}_{2.5}$ levels to 20 micrograms per cubic meter of air, while the average between 2017 and 2019 was four times this value (ZHANG et al., 2020).

\section{FINAL CONSIDERATIONS}

The presented data show how much pollution can decrease when transport within cities is curtailed, even though this came at the 'cost' of decreasing human activity with consequences for the global economy. Nevertheless, it clearly shows the rapidity with which air pollution can be diminished given changes in human behaviour.

Given the Covid-19 pandemic obligated humanity to review and reflect upon its development, in a post-Covid world, governments and their citizens may wish to retain some of the benefits, such as cleaner air, reducing human activities - especially if these are achievable without impeding economic activity. This may require a new development model that foregrounds green infrastructure, sustainable transport solutions and more flexible work practices.

Although humanity has already caused several negative environmental impacts, observing nature can recover, even if slowly, by reducing anthropogenic interference in the environment, brings hope for a less ill future.

São Paulo and Rio de Janeiro are two major commercial and industrial hubs, among the most important cities globally. Both are moving towards generating the first megalopolis in the country, with high levels of social inequality, accommodating slums and financial transactions with international visibility almost at the same level.

The decrease in activities in these regions represents much more than just the decrease in vehicle circulation. When observing the national scenario, it is possible to verify that most of the actions circumvented the presidential statement that there was no reason for concern. Other studies may assess the unemployment rate or how the recklessness of government officials affected the Brazilian economy or the collapse in the health system due to people's disbelief. A comparative study of the period in this paper with 2021 data might be interesting as well since social isolation has dropped and the misery in which the population finds itself increased.

According to the study results, it was observed that the reduction of pollutant emissions in the cities of São Paulo and Rio de Janeiro, especially $\mathrm{NO}_{2}$ and $\mathrm{CO}$, was a positive externality of the lower economic activity caused by the pandemic in both cities. These results imply, cumulatively, signalling the reduction in mortality from respiratory diseases directly linked to air pollution, as reinforced by other studies in this paper.

The reduction in the discharge of atmospheric pollutants varies according to many factors, such as time of day, humidity, wind, etc. But also due to greater or lesser restriction policies on urban mobility. This phenomenon is also occurring in other cities in the world affected by the Covid-19 pandemic. These cities should reflect upon measures for gradual and consistent improvement of air quality by way of institutionalization of permanent air-quality control, in a way that should not imply negative economic externalities such as the increase of unemployment in the urban areas. The final remarks reinforce the need for further studies. These could help us evaluate, in a comparative way, how the 
association between political measures to control the Covid-19 pandemic implied in air pollutants emission reduction. Similar studies can reveal positive effects on public health.

\section{ACKNOWLEDGMENTS}

The authors are thankful to the Coordination for the Improvement of Higher Education Personnel (Capes) for their financial support and to the Tiradentes University Centre for the analyses conducted at their facilities.

\section{REFERENCES}

AGRAS, J.; CHAPMAN, D. A dynamic approach to the Environmental Kuznets Curve hypothesis. Ecological Economics, v. 28, n. 2, p. 267-277, 1999.

AMARAL, A.C. Imagens de satélite mostram que mancha de poluição em SP se reduziu na quarentena contra coronavírus. Folha de São Paulo, São Paulo, abr. 2020. Available in: <https://www1.folha.uol.com.br/ambiente/2020/04/ imagens-de-satelite-mostram-que-mancha-de-poluicao-em-sp-se-reduziu-na-quarentena-contra-coronavirus. shtml?pwgt=klpjmh99gcyzto3eddti7z0uafwthqrkmf75cfebyww86znm>. Access in: 19 may 2020.

ANDERSEN, K. G. et al. The proximal origin of SARS-CoV-2. Nature Medicine, v. 26, p. 450-452, 2020.

CANÇADO, J. E. D. et al. Repercussões clínicas da exposição à poluição atmosférica. Jornal Brasileiro de Pneumologia, Brasília, v. 32, n. 2, 2006.

COKER, E. S. et al. The Effects of Air Pollution on Covid-19 Related Mortality in Northern Italy. Environmental and Resource Economics, v. 76, p. 611-634, 2020.

COMPANHIA AMBIENTAL DO ESTADO DE SÃO PAULO. Emissões veiculares no estado de São Paulo 2017. São Paulo: Cetesb, 2018.

CONAMA. Resolução Conama no 3, de 28 de junho de 1990. Dispõe sobre padrões de qualidade do ar, previstos no Pronar. Diário Oficial da União, no 158, de 16 de aug de 1990, p. 15518-15519.

CORONAVIRUS lockdown leading to drop in pollution across Europe. National Aeronautics And Space Administration, Virginia, Mar. 2020. Available in: <https://airquality.gsfc.nasa.gov/news/coronavirus-lockdownleading-drop-pollution-across-europe>. Access in: 19 may 2020.

COVID-19. Boletins informativos e casos do coronavírus por município por dia. Abr. 2020. Available in: <https:// brasil.io/dataset/covid19/caso>. Access in: 01 abr. 2020.

DEBONE, D.; COSTA, M. V.; MIRAGLIA, S. G. E. K. 90 Days of Covid-19 Social Distancing and Its Impacts on Air Quality and Health in Sao Paulo. Brazil. Sustainability, v. 12, n. 18, 2020.

DIAS, F. L. et al. Using Seismic Noise Levels to Monitor Social Isolation: an example from Rio de Janeiro, Brazil. Geophysical Research Letters, v. 47, n. 16, 2020.

EPA. Air Quality Index (AQI): a guide to air quality and your health. New York: EPA; 2009.

FAíCO-FILHO, K. S. et al. Covid-19 in health care workers in a university hospital during the quarantine in São Paulo city. The Brazilian Journal of Infectious Diseases, v. 24, n. 5, p 462-465, 2020.

FERNANDES, C. M. et al. A pós-verdade em tempos de Covid-19: o negacionismo no discurso do governo no Instagram. Liincem Revista, Rio de Janeiro, v. 16, n. 2, e5317, 2020. 
FOLHA informativa - Covid-19. Pan American Health Organization, Brasília, abr. 2020. Available in: <https://www.paho. org/bra/index.php?option=com_content\&view=article\&id=6101:covid19\&Itemid=875>. Access in: 14 apr. 2020.

FORO de las Sociedades Respiratorias Internacionales. El impacto global de la Enfermedad Respiratoria, 2. ed. México: Asociación Latinoamericana de Tórax, 2017.

FREITAS, E. D. et al. Mobility restrictions and air quality under Covid-19 pandemic in São Paulo, Brazil. Preprints 2020, 2020040515.

GALHARDI, C. P. et al. Fato ou Fake? Uma análise da desinformação frente à pandemia da Covid-19 no Brasil. Ciência e Saúde Coletiva, Rio de Janeiro, v. 25, supl. 2, p. 4201-4210, 2020.

GAVINIER, S.; NASCIMENTO, C. F. L. Poluentes atmosféricos e internações por acidente vascular encefálico. Ambiente \& Água - An Interdisciplinary Journal of Applied Science, Taubaté, v. 9, n. 3, jul./sep. 2014.

HAN, L. et al. Multicontaminant air pollution in Chinese cities. Bulletin of the World Health Organization, 2018, p. $96-233-242 E$.

HSIANG, S. et al. The effect of large-scale anti-contagion policies on the Covid-19 pandemic. Nature, v. 584, n. 7820, p. 262-267, 2020.

INSTITUTO BRASILEIRO DE GEOGRAFIA E ESTATÍSTICA. São Paulo. IBGE, abr. 2018a. Available in: <https://cidades. ibge.gov.br/brasil/sp/sao-paulo/pesquisa/22/28120?tipo=grafico>. Access in: 24 apr. 2020.

INSTITUTO BRASILEIRO DE GEOGRAFIA E ESTATÍSTICA. Rio de Janeiro. IBGE, abr. 2018b. Available in: <https:// cidades.ibge.gov.br/brasil/rj/rio-de-janeiro/pesquisa/22/28120?tipo=grafico>. Access in: 24 apr. 2020.

INSTITUTO ESTADUAL DO MEIO AMBIENTE. Inventário: emissões de fontes veiculares. Região Metropolitana do Rio de Janeiro. Ano-base 2013. Rio de Janeiro: Inea, 2016.

JONES, L.; PALUMBO, D.; BROWN, D. Coronavirus: a visual guide to the economic impact. BBC News, abr. 2020. Available in: <https://www.bbc.com/news/business-51706225?intlink_from_url=\&>. Access in: 28 apr. 2020.

KOSLOWSKI, L. A. D. et al. Estudo dos gases da combustão provenientes do diesel S10 e S50. In: CONGRESSO INTERNACIONAL DE TECNOLOGIAS PARA O MEIO AMBIENTE, 4., 2014, Bento Gonçalves. Anais [...] Bento Gonçalves: 2014.

KURIYAMA, G. S.; MOREIRA, J. C.; SILVA, C. R. S. Exposição ocupacional ao dióxido de nitrogênio ( $\mathrm{NO}_{2}$ ) em policiais de trânsito na cidade do Rio de Janeiro. Cadernos de Saúde Pública, Rio de Janeiro, v. 13, n. 4, oct./dec. 1997.

LIAN, X. et al. Impact of city lockdown on the air quality of Covid-19-hit of Wuhan city. Science of the Total Environment, v. 742, 2020.

LI, R. et al. Substantial undocumented infection facilitates the rapid dissemination of novel coronavirus (SARSCoV2). Science, 2020.

MAIER, B. F.; BROCKMANN, D. Effective containment explains subexponential growth in recent confirmed Covid-19 cases in China. Science, v. 368, n. 6492, p. 742-746, 2020.

MANAHAN, S. E. Química ambiental. 9. ed. Porto Alegre: Bookman, 2013.

MARTINS, C. R.; DE ANDRADE, J. B. Química atmosférica do enxofre (IV): emissões, reações em fase aquosa e impacto ambiental. Química Nova, São Paulo, v. 25, n. 2, p. 259-272, 2002.

MUHAMMAD, S.; LONG, X.; SALMAN, M. 2020. Covid-19 pandemic and environmental pollution: a blessing in disguise? Sci. Total Environ. v. 728, 138820, 2020.

ORGANIZAÇÃO Mundial da Saúde declara pandemia de coronavírus. Agência Brasil, Mar. 2020. Available in: <https://agenciabrasil.ebc.com.br/geral/noticia/2020-03/organizacao-mundial-da-saude-declara-pandemia-decoronavirus>. Access in: 30 mar. 2020. 
PERES, F. F. Meio ambiente e saúde: os efeitos fisiológicos da poluição do ar no desempenho físico - o caso do monóxido de carbono. Arquivos em Movimento, v. 1, n. 1, p. 55-63, jan/jun 2005.

PRIMEIRO hospital de campanha do Rio é inaugurado no Leblon com 30 leitos. G1 Rio, mar. 2020. Available in: <https://g1.globo.com/rj/rio-de-janeiro/noticia/2020/04/25/hospital-de-campanha-no-rio-antecipa-inauguracaopara-este-sabado-com-30-leitos.ghtml>. Access in: 14 may 2020.

RIO DE JANEIRO (Estado). Decreto Estadual no 46.973, de 16 de março de 2020. Reconhece a situação de emergência na saúde pública do Estado do Rio de Janeiro em razão do contágio e adota medidas de enfrentamento da propagação do novo Coronavírus - Covid-19, e dá outras providências. Diário Oficial do Estado do Rio de Janeiro, seção 1, seção 1, Rio de Janeiro, RJ, ano 46, n. 49, p. 1-42, 17 mar. 2020a.

RIO DE JANEIRO (Estado). Decreto Estadual no 46.980, de 19 de março de 2020. Atualiza as medidas de enfrentamento da propagação decorrente do novo coronavírus (Covid-19) em decorrência da situação de emergência em saúde e dá outras providências. Diário Oficial do Estado do Rio de Janeiro, parte 1, Rio de Janeiro, RJ, ano 46, n. 051-B, p. 1-2, 19 mar. 2020b.

RIO DE JANEIRO (Estado). Decreto Estadual no 47.025, de 07 de abril de 2020. Dispõe sobre a liberação de atividade comercial em municípios sem notificação de cometimento da Covid-19, e dá outras providências. Diário Oficial do Estado do Rio de Janeiro, parte 1, Rio de Janeiro, RJ, ano 46, n. 065, p. 1, 07 apr. 2020 e.

RIO DE JANEIRO (Município). Decreto Municipal no 47.282, de 21 de março de 2020. Determina a adoção de medidas adicionais, pelo Município, para enfrentamento da pandemia do novo Coronavírus - Covid-19, e dá outras providências. Diário Oficial do Município do Rio de Janeiro, seção 1, Rio de Janeiro, RJ, ano 34, n. 6, p. 1-4, 21 mar. 2020c.

RIO DE JANEIRO (Município). Decreto Municipal no 47.301, de 26 de março de 2020. Altera o Decreto Rio no 47.282 , de 21 de março de 2020, que determina a adoção de medidas adicionais, pelo Município, para enfrentamento da pandemia do novo Coronavírus - Covid-19, e dá outras providências. Diário Oficial do Município do Rio de Janeiro, seção 2, Rio de Janeiro, RJ, ano 34, n. 10, p. 1-4, 27 mar. 2020 d.

RIO DE JANEIRO (Município). Coronavírus: veja aqui as medidas adotadas pela Prefeitura nesta sexta-feira para conter a pandemia na cidade. Prefeitura do Rio de Janeiro, Mar. 2020f. Available in: <https://prefeitura.rio/bemestar-animal/coronavirus-veja-aqui-as-medidas-adotadas-pela-prefeitura-nesta-sexta-feira-para-conter-a-pandemiana-cidade/>. Access in: 11 mai. 2020.

RIO DE JANEIRO (Município). Coronavírus: veja aqui as medidas adotadas pela Prefeitura nesta segunda-feira para conter a pandemia na cidade. Prefeitura do Rio de Janeiro, Mar. 2020g. Available in: <https://prefeitura. rio/assistencia-social-direitos-humanos/coronavirus-veja-aqui-as-medidas-adotadas-pela-prefeitura-nesta-segundafeira-para-conter-a-pandemia-na-cidade/>. Access in: 11 may 2020.

RIO DE JANEIRO (Município). BRT Transoeste tem operação interrompida neste fim de semana por causa de coronavírus. Prefeitura do Rio de Janeiro, Mar. 2020h. Available in: <https://prefeitura.rio/transportes/brttransoeste-tem-operacao-interrompida-neste-fim-de-semana/>. Access in: 11 may 2020.

RIO DE JANEIRO (Município). Características Geográficas. Prefeitura do Rio de Janeiro, 2009. Available in: <https:// www.rio.rj.gov.br/web/riotur/caracteristicas-geograficas>. Access in: 14 may 2020.

ROY, N.; CHAUBE, R. Environmental impact of Covid-19 pandemic in India International. Journal of Biological Innovations, v. 3, n. 1, p. 48-57, 2021.

SANTOS, M. A. Poluição do meio ambiente. Rio de Janeiro: LTC, 2017.

SÃO PAULO (Estado). Decreto Estadual no 64.879, de 20 de março de 2020. Reconhece o estado de calamidade pública, decorrente da pandemia da Covid-19, que atinge o Estado de São Paulo, e dá providências correlatas. Diário Oficial do Estado de São Paulo, seção 1, São Paulo, SP, v. 130, n. 56, p. 1-186, 21 mar. 2020 b.

SÃO PAULO (Estado). Decreto Estadual no 64.881, de 22 de março de 2020. Decreta quarentena no Estado de São Paulo, no contexto da pandemia da Covid-19 (Novo Coronavírus), e dá providências complementares. Diário Oficial do Estado de São Paulo, seção 1, São Paulo, SP, v. 130, n. 57, p. 1-186, 23 mar. 2020c. 
SÃO PAULO (Estado). Decreto Estadual no 64.946, de 17 de abril de 2020. Estende a medida de quarentena de que trata o Decreto no 64.881, de 22 de março de 2020. Diário Oficial do Estado de São Paulo, seção 1, São Paulo, SP, v. 130, n. 76,23 apr. 2020 d.

SÃO PAULO (Estado). Prefeitura adéqua temporariamente frota de ônibus na Capital. Prefeitura de São Paulo, Mar. 2020g. Available in: <https://www.prefeitura.sp.gov.br/cidade/secretarias/transportes/noticias/?p=29557>. Access in: 11 may 2020.

SÃO PAULO (Estado). Secretaria de Energia. Atlas Eólico do Estado de São Paulo. São Paulo: Governo do Estado de São Paulo, 2012.

SÃO PAULO (Município). Decreto Municipal no 59.283, de 16 de março de 2020. Declara situação de emergência no Município de São Paulo e define outras medidas para o enfrentamento da pandemia decorrente do coronavírus. Diário Oficial da Cidade de São Paulo, seção 1, São Paulo, SP, ano 65, n. 54, p. 1-106, 17 mar. 2020 a.

SÃO PAULO (Município). Rodízio Municipal de Veículos. Prefeitura de São Paulo, Mar. 2020e. Available in: <https://www.prefeitura.sp.gov.br/cidade/secretarias/transportes/noticias/?p=295203>. Access in: 11 may 2020.

SÃO PAULO (Município). Circulação de veículos pesados para abastecimento. Companhia de Engenharia de Tráfego, Mar. 2020f. Available in: <http://www.cetsp.com.br/noticias/2020/03/19/nota-a-imprensa-\%E2\%80\%93circulacao-de-veiculos-pesados-para-abastecimento.aspx>. Access in: 11 may 2020.

SHARMA, P.; KAUR, M.; NARWAL, G. Other side of the Covid-19 Pandemic: a review. The Pharma Innovation Journal, v. 9, n. 5, p. 366-369, 2020.

SOUZA, A. et al. Estudo da associação entre óxidos de nitrogênio e concentração de ozônio com parâmetros meteorológicos. Geosul, Florianópolis, v. 33, n. 68, p. 164-183, sep./dec. 2018.

TÉLLEZ, J.; RODRÍGUEZ, A.; FAJARDO, Á. Contaminación por Monóxido de Carbono: un problema de salud ambiental. Revista de Salud Pública, v. 8, n. 1, p. 108-117, 2006.

TRAVAGLIO, M. et al. Links between air pollution and Covid-19 in England. Environmental Pollution, v. 268, Part A, 2021.

UEDA, A. C.; TOMAZ, E. Inventário de emissão de fontes veiculares da Região Metropolitana de Campinas, São Paulo. Química Nova, São Paulo, v. 34, n. 9, São Paulo, sep. 2011.

YANPING, Z. The epidemiological characteristics of an outbreak of 2019 novel coronavirus diseases (Covid-19) in China. Chinese Journal of Epidemiology, Beijing, v. 41, n. 2, p. 145-151, 2020.

ZHANG, L. et al. The changing PM2.5 dynamics of global megacities based on long-term remotely sensed observations. Environment International, v. 142, 2020. 